\title{
A new subfamily, Vulcanocalliacinae n.subfam., for Vulcanocalliax arutyunovi n.gen., n.sp. from a mud volcano in the Gulf of Cádiz (Crustacea, Decapoda, Callianassidae)
}

\author{
PETER C. DWORSCHAK ${ }^{1,3} \&$ MARINA R. CUNHA ${ }^{2}$ \\ ${ }^{\prime}$ Dritte Zoologische Abteilung, Naturhistorisches Museum, Burgring 7, A 1010 Wien, Austria. \\ E-mail: Peter.Dworschak@nhm-wien.ac.at \\ ${ }^{2}$ CESAM (Centro de Estudos do Ambiente e do Mar), Departamento de Biologia, Universidade de Aveiro, Campus de Santiago, $3810-$ \\ 193 Aveiro, Portugal.E-mail: mcunha@bio.ua.pt \\ ${ }^{3}$ Corresponding author
}

\begin{abstract}
A new ghost shrimp, Vulcanocalliax arutyunovi n.gen. n.sp., is described and accommodated in the new subfamily Vulcanocalliacinae. This subfamily shares with the Bathycalliacinae Sakai \& Türkay, 1999 the presence of epipods on the third maxilliped and the first four pairs of pereopods, but differs by the absence of cardiac sulci and a dorsomedian carina. This is the second record of a thalassinidean crustacean from deep-sea chemoautotrophic communities.
\end{abstract}

Key words: Callianassidae, Vulcanocalliacinae, Vulcanocalliax, new subfamily, new genus, new species, Gulf of Cádiz, mud volcanoes, deep water

\section{Introduction}

Productive ecosystems associated with cold seeps are sustained by the release of methane-rich fluids of thermogenic and/or biogenic origin and by sulphide production via sulphate reduction in the sediment, which are used as the main sources of energy for free-living and endosymbiontic microbial production (Olu et al., 1997). In a comprehensive review of cold seep communities, Sibuet \& Olu (1998) mentioned 24 known locations from the Atlantic, the Eastern and Western Pacific Oceans and the Mediterranean Sea. Since then, cold seep occurrence has proved to be a widespread phenomenon and many other locations have been discovered both in active and passive margins. Mud volcanoes are seepage-related geomorphological features and provide strong indication of fluid venting (Ivanov et al., 1998). The most extensive area of active mud volcanism known from the European margins was recently discovered in the Gulf of Cádiz (southern Iberian and northern Moroccan margins, west of Gibraltar Strait) and has been intensively investigated within the framework of the UNESCO/IOC Training-Through-Research (TTR) Programme (e.g. Kenyon et al., 2000; Pinheiro et al., 2003; Van Rensbergen et al., 2005; Stadnitskaia et al., 2006).

The Gulf of Cádiz contains over 30 mud volcanoes at depths between 200 and $4000 \mathrm{~m}$, with varying degrees of methane expulsion activity. Since 1999 an exploratory biological program has been carried out during yearly TTR cruises. Decapods were found to be common inhabitants of mud volcanoes: pandalid shrimps, galatheids and large crabs [e.g. Paromola cuvieri (Risso, 1816)] were often sighted during deep-towed video observations but seldom found in benthic samples. Up to now, eleven decapod species have been collected but, except for the xanthid crab Monodaeus couchi (Couch, 1851) that occurs in several mud volcanoes, most records are based on single specimens. In Captain Arutyunov mud volcano, one of the most active sites, an unusual member of the Callianassidae has been found. 
Very few thalassinidean shrimp have been reported from hydrothermally influenced areas. Martin \& Haney (2005), in their review of the decapod crustaceans associated with hydrothermal vents and cold seeps, state "The thalassinoid ('mud shrimp') families Axiidae, Callianassidae and Calocarididae (all reported from the Gulf of Mexico) are represented by species as yet undescribed, with the exception of one recently described axiid [Calaxius carneyi Felder \& Kensley, 2004] from the Gulf and one vagrant callianassid species [Callianassa truncata Giard \& Bonnier, 1890] reported from a shallow volcanic system in the Aegean Sea." These authors unfortunately overlooked two species previously reported from such environments. The first is Paraglypturus calderus Türkay \& Sakai, 1995, found in quite shallow water (63-114 m) at a caldera of a submerged volcano in the Marianas, Pacific Ocean. The second species and first member of the Callianassidae found from hydrothermally influenced habitats in the deep sea is Bathycalliax geomar Sakai \& Türkay, 1999 from cold seeps in 625-627 m off Oregon, USA.

The present specimens are the first records of callianassids from chemoautotroph communities at the deep sea bottom in the Atlantic and exhibit a series of unique characters. We propose the designation of a new subfamily, the Vulcanocalliacinae, to accommodate these unusual shrimps.

\section{Material and methods}

Captain Arutyunov is an individual, cone-shaped mud volcano on a flat basin floor discovered during the TTR12 cruise (Kenyon et al., 2003). It is about $100 \mathrm{~m}$ high, $2 \mathrm{~km}$ in diameter and has a $300 \mathrm{~m}$ wide circular crater at the top, centered at $35^{\circ} 39.71 \mathrm{~N}$ and $7^{\circ} 19.98^{\prime} \mathrm{W}$ and $1324 \mathrm{~m}$ depth. At the surroundings the fauna is scarce but there are numerous burrows arranged in clusters at the lower flanks. The crater's structure is formed by a series of concentric facies (strong backscattering in the side-scan sonar images): the outer facies (rim) is a green mud with a smooth surface characterised by the presence of small mounds of bioturbated sediment (mud breccia); the middle facies is a ring of disturbed green mud with numerous buccinid shells and pebbly clasts; in the central facies the seafloor is rippled - the mud here is covered by numerous clasts and shells and has a patchy appearance. The most conspicuous animals were cidarid echinoids clustered at the center of the crater. Several samples taken at the top showed that the central area is rich in gas hydrates and is densely covered by aggregations of Siboglinum accompanied by buried thyasirid bivalves and patches of abundant polychaetes and tanaidaceans. A weak current to the northwest runs over most of the volcano; on the southern slope a slightly stronger current flows to the west-southwest.

Samples were collected during the TTR12 cruise onboard the RV Prof. Logachev. Side-scan sonar imagery of the mud volcano allowed areas of high reflectivity to be identified; these were then surveyed with a deep-towed video system. A TV-guided grab was used to locate and sample selected targets in the mud volcano. This two-spade, electro-hydraulic grab sampled an area of $1.5 \mathrm{~m}^{2}$ to a sediment depth of ca $70 \mathrm{~cm}$. The biological material was preserved in $70 \%$ ethanol.

The types have been deposited in the Naturhistorisches Museum Wien, Austria (NHMW). Size is expressed as total length ( $\mathrm{tl}$ in $\mathrm{mm}$ ) from the tip of the rostrum to the end of the telson and as carapace length ( $\mathrm{cl}$ in $\mathrm{mm}$ ) from the tip of the rostrum to the posterior median edge of the carapace. Other abbreviations include: SMF, Forschungsinstitut Senckenberg, Frankfurt am Main, Germany; A1, first antenna (antennule); A2, second antenna; Mxp1-3, first to third maxilliped; P1-P5, first to fifth pereopod; Plp1-Plp5, first to fifth pleopod.

Comparative material examined: Bathycalliax geomar Sakai \& Türkay, 1999; holotype SMF 23866, female (tl 57, cl 13.0), Pacific, Aleutian Subduction-Zone off Oregon, USA, 44 40.146' N $125^{\circ} 06.685^{\prime} \mathrm{W}$, So109/119, 625 m depth, TV-grab, 24 March 1996, RV Sonne; paratype SMF 23867 (tl 48, cl 11.5), Pacific,

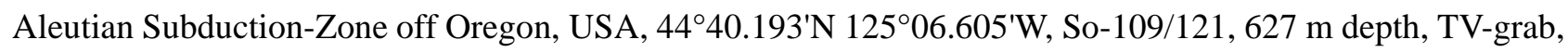
25 March 1996, RV Sonne. Ctenocheles maorianus Powell, 1949, NHMW 6733, 1 female, S. New Zealand, Little Town, Reischek coll. 


\section{Taxonomy}

\section{Vulcanocalliacinae n.subfam.}

Diagnosis: Carapace without dorsal oval, without median carina, without transverse cardiac sulci. Mxp3 ischium-merus 2.5 times as long as broad, dactylus broadened. Plp3-5 biramous, larger than Plp1-2. Epipods present on Mxp3-P4.

Type genus: Vulcanocalliax n.gen., by monotypy and present designation.

Remarks: According to Sakai (2005), the family Callianassidae Dana, 1852 includes eight subfamilies, the Callianassinae Dana, 1852, Callichirinae Manning \& Felder, 1991, Eucalliacinae Manning \& Felder, 1991, Anacalliacinae Manning \& Felder, 1991, Calliapaguropinae Sakai, 1999, Lipkecallianassinae Sakai, 2005, Bathycalliacinae Sakai \& Türkay, 1999 and Paracalliacinae Sakai, 2005. Vulcanocalliacinae n.subfam. shares with Bathycalliacinae Sakai \& Türkay, 1999 the presence of epipods on Mxp3-P4, but differs from the latter by the absence of cardiac sulci and the absence of a dorsomedian carina. Both subfamilies show a cardiac prominence which is a common character of the family Ctenochelidae (sensu Manning \& Felder, 1991). In Bathycalliacinae this cardiac prominence is a distinct swelling close to the posterior border of the carapace (see Sakai \& Türkay, 1999: figs 1, 2a) and similar to that in the Ctenochelidae [e.g. in Ctenocheles maorianus Powell, 1949 (NHMW 6733); Ctenocheles balssi Kishinouye, 1926 (see Sakai, 1999a: fig. 1a); see also Manning \& Felder (1991: figs 2 and 7)]. In Vulcanocalliacinae n.subfam., the swelling is less pronounced and situated more anteriorly between cervical grove and posterior border of the carapace than in the Ctenochelidae, similar to the weak cardiac prominence found in some members of the Eucalliacinae (e.g. Calliax doerjesti Sakai, 1999b: fig. 28).

\section{Vulcanocalliax n.gen.}

Diagnosis: Carapace lacking dorsal oval and median carina. Cervical groove present, transverse cardiac sulci absent. Weak cardiac prominence bearing a small pit. Sixth abdominal somite without lateral projections. Eyestalks dorsally depressed, stalks in contact with each other medially; corneas lacking. Second maxilla scaphognathite lacking long posterior seta. Mxp3 ischium-merus 2.5 times as long as broad, lacking exopod. Epipods present on Mxp3 through P4. Uropodal exopod oval, anterodorsal plate with strongly convex posterior margin. Male Plp2 with appendix interna.

Type species: Vulcanocalliax arutyunovi n.sp., by monotypy and present designation.

Etymology: The name is a combination of vulcano (Latin for volcano), derived from Vulcanos, the Roman god of fire, for the mud volcano habitat in which it was collected, combined with Calliax. The gender is feminine, as in Calliax.

Remarks: The new genus is similar to Bathycalliax Sakai \& Türkay, 1999 with respect to the presence of epipods on Mxp3 to P4, the shape of Mxp3, the shape of P3 propodus, the general shape of the tailfan, and the shape of the eyes, which lack a cornea. Vulcanocalliax n.gen. differs from Bathycalliax in the absence of a dorsomedian carina, the absence of cardiac sulci, and the absence of an exopod on Mxp3.

\section{Vulcanocalliax arutyunovi n.sp.}

(Figures 1-5, Table 1)

Material: Holotype NHMW 21927, ovigerous female (tl 55, cl 14.2, dissected), Atlantic Ocean, Gulf of Cádiz, Captain Arutyunov mud volcano, 35³9.805'N 07¹9.997'W, 1339 m, TTR12 station AT399GR, 13 July 2002, RV Prof. Logachev, TV-guided grab. Allotype NHMW 21928, juvenile male (tl 18.5, cl 5.4), same 
locality as holotype, $35^{\circ} 39.740^{\prime} \mathrm{N} 07^{\circ} 19.942^{\prime} \mathrm{W}, 1327 \mathrm{~m}$, TTR 12 station AT393GR, 9 July 2002, RV Prof. Logachev, TV-guided grab.

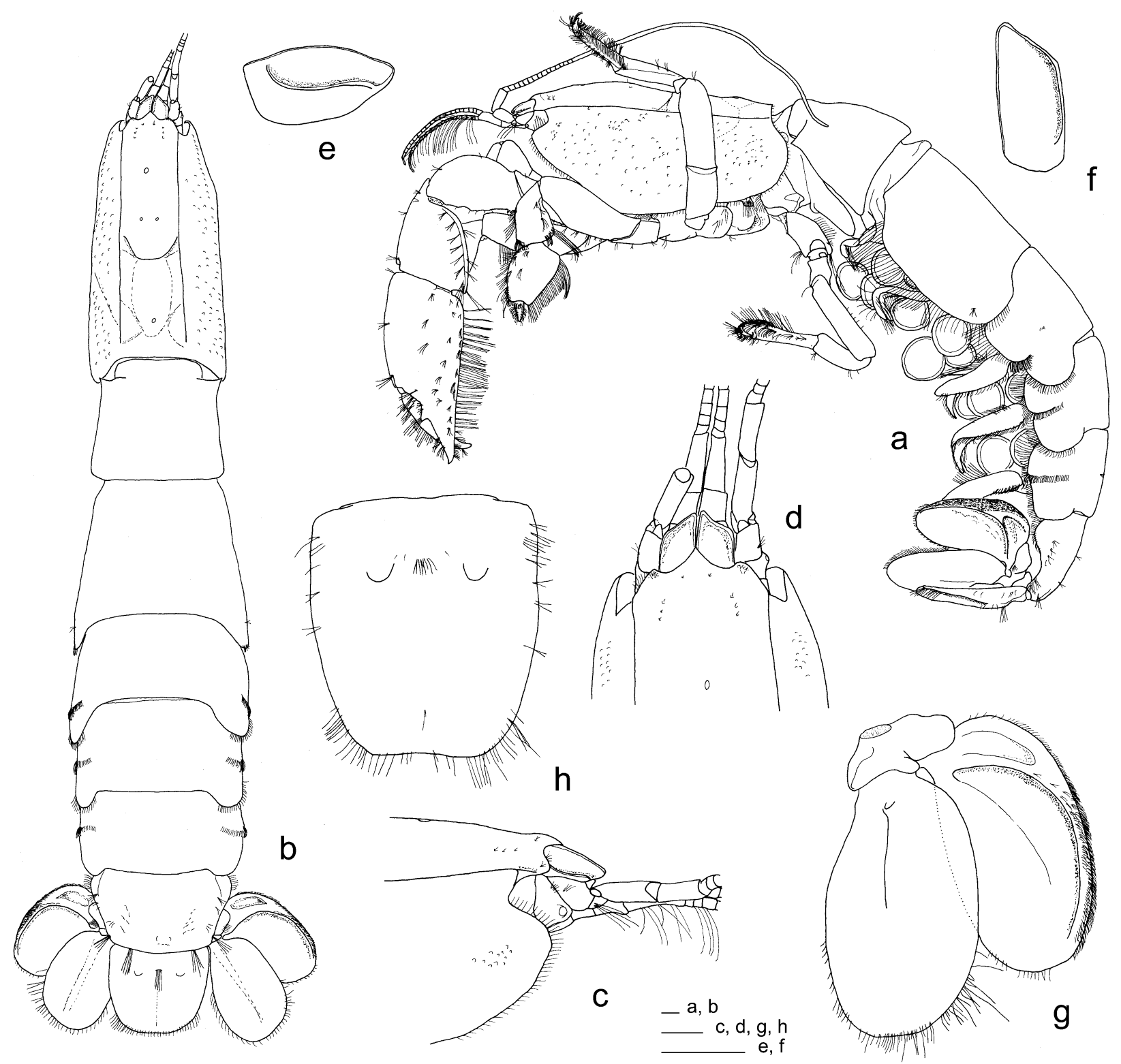

FIGURE 1. Vulcanocalliax arutyunovi n.gen. n.sp., female holotype (NHMW 21927): a, lateral view; b, dorsal view; c, front in lateral view; d, same, dorsal aspect; e, lateral aspect of right eyestalk; f, same, dorsal aspect; g, dorsal aspect of uropods; h, dorsal aspect of telson. Scale lines indicate $1 \mathrm{~mm}$.

Description of female holotype: Dorsally, carapace as long as abdominal somites 1 and 2 combined (Fig. 1a, b). Frontal margin of carapace with narrow triangular acute rostrum, flanked by excavated shoulders forming anteriorly produced rounded prominences lateral to margins of eyestalks; rostrum extending to 0.3 times the visible length of eyestalks in dorsal view (Fig. 1c, d). Lateral projections of carapace setose dorsally. Carapace lacking distinct dorsal oval and dorsal carina. A single median pit dorsally halfway between rostrum and distinct cervical groove, one pair of smaller pits anterior to cervical groove. Indistinct cardiac prominence bearing median pit in posterior fourth of carapace. Transverse sutures indistict to absent. Linea thalassinica strong, parallel to midline of carapace. Lateral surface of carapace finely tuberculate, ventral margin with short setae. Subantennular region of epistome bearing a few long setae. 


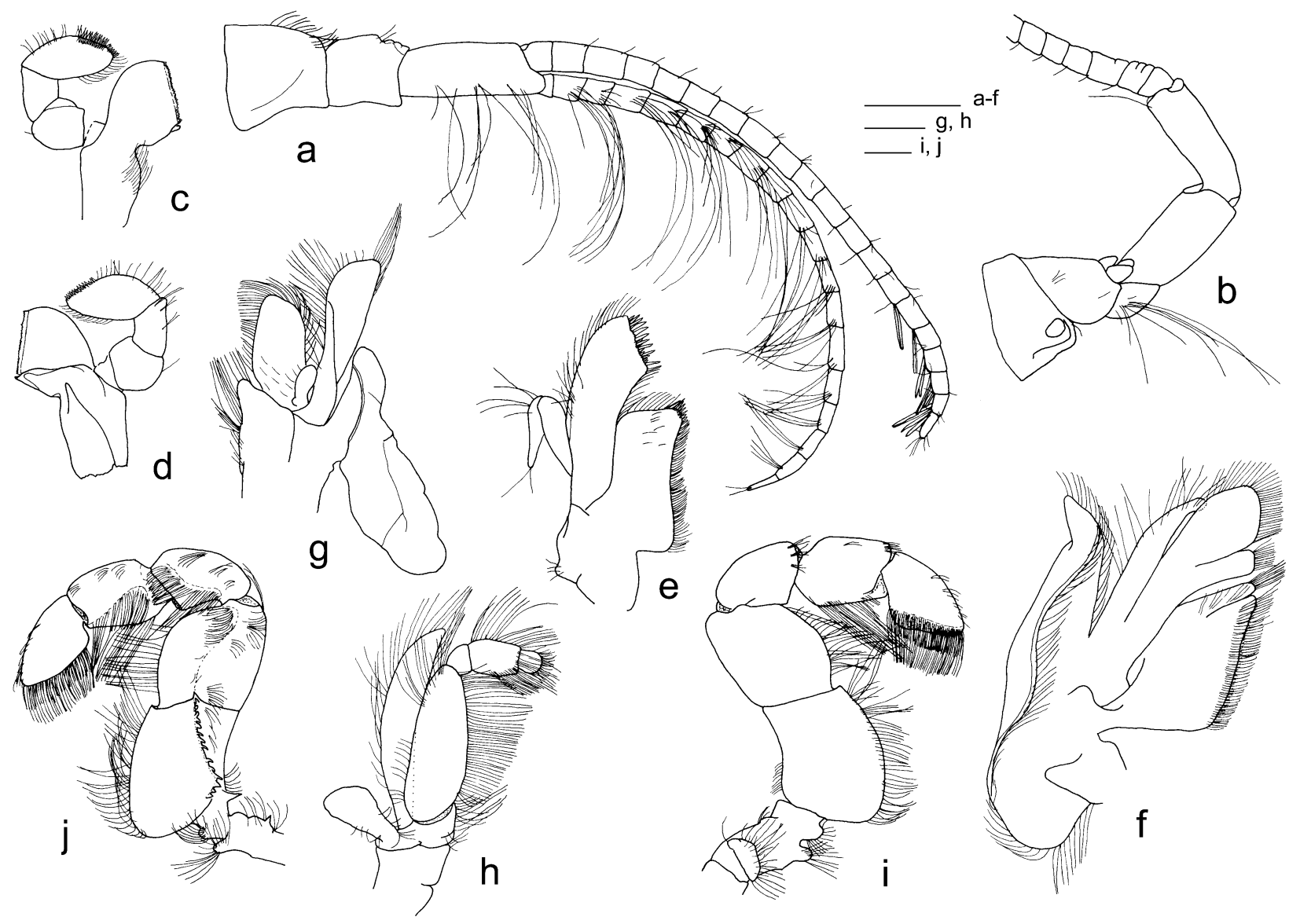

FIGURE 2. Vulcanocalliax arutyunovi n.gen. n.sp., female holotype (NHMW 21927), right appendages; a-c, e, f, h, i, lateral surface; d, g, j, mesial surface: a, first antenna; b, second antenna; c, d, mandible, excluding paragnaths; e, first maxilla; f, second maxilla; g, first maxilliped; h, second maxilliped; i, j, third maxilliped. Scale lines indicate $1 \mathrm{~mm}$.

Eyestalks (Fig. 1e, f) dorsally flattened and depressed, slightly convex ventrally, keeled laterally, length 2.3 times width, in dorsal view reaching beyond basal antennal article; mesial surfaces flattened so eyestalks abutt closely at midline over entire length; lateral margin parallel to midline in proximal three quarters, tapering distally, no cornea or pigment detectable.

Antennular peduncle shorter than antennal peduncle (Figs. 1d, 2a); basal article laterally inflated, with long setae dorsally near distal end; second article 0.76 times length of basal article with few dorsal setae near distal end, third article about 2 times length of second, with ventrolateral row of long, ventrally directed setae continued onto ventral ramus of flagellum; rami of flagellum about equal length, near 5 times length of third article of peduncle; dorsal ramus with few short setae, subterminal articles of dorsal ramus thicker than those of ventral ramus, bearing dense line of ventral aesthetascs (Fig. 2a).

Antennal peduncle 1.2 times length of antennular peduncle (Fig. 2b); basal article with ventrolaterally produced excretory pore; second article with deep, diagonal ventrolateral furrow, distally with field of long setae below ventrolateral suture; rounded, articulated dorsal scale at joint proximal to third article; third article elongate, same length as fourth or combined length of first two, fourth article narrower than third; flagellum sparsely setose, extending posteriorly to middle of pleonite 1.

Mandible (Fig. 2c, d) with large, terminally setose, 3-segmented palp, third article of palp terminally rounded; incisor process thin, with minute teeth on cutting margin, mesial surface with lip giving rise to molar process proximal to incisor process. 
First maxilla (Fig. 2e) with endopodal palp long, narrow, terminal article deflected proximally at articulation; proximal endite setose on straight margin, terminally with field of thick simple setae; distal endite elongate, terminally truncate and armed with stiff simple setae.

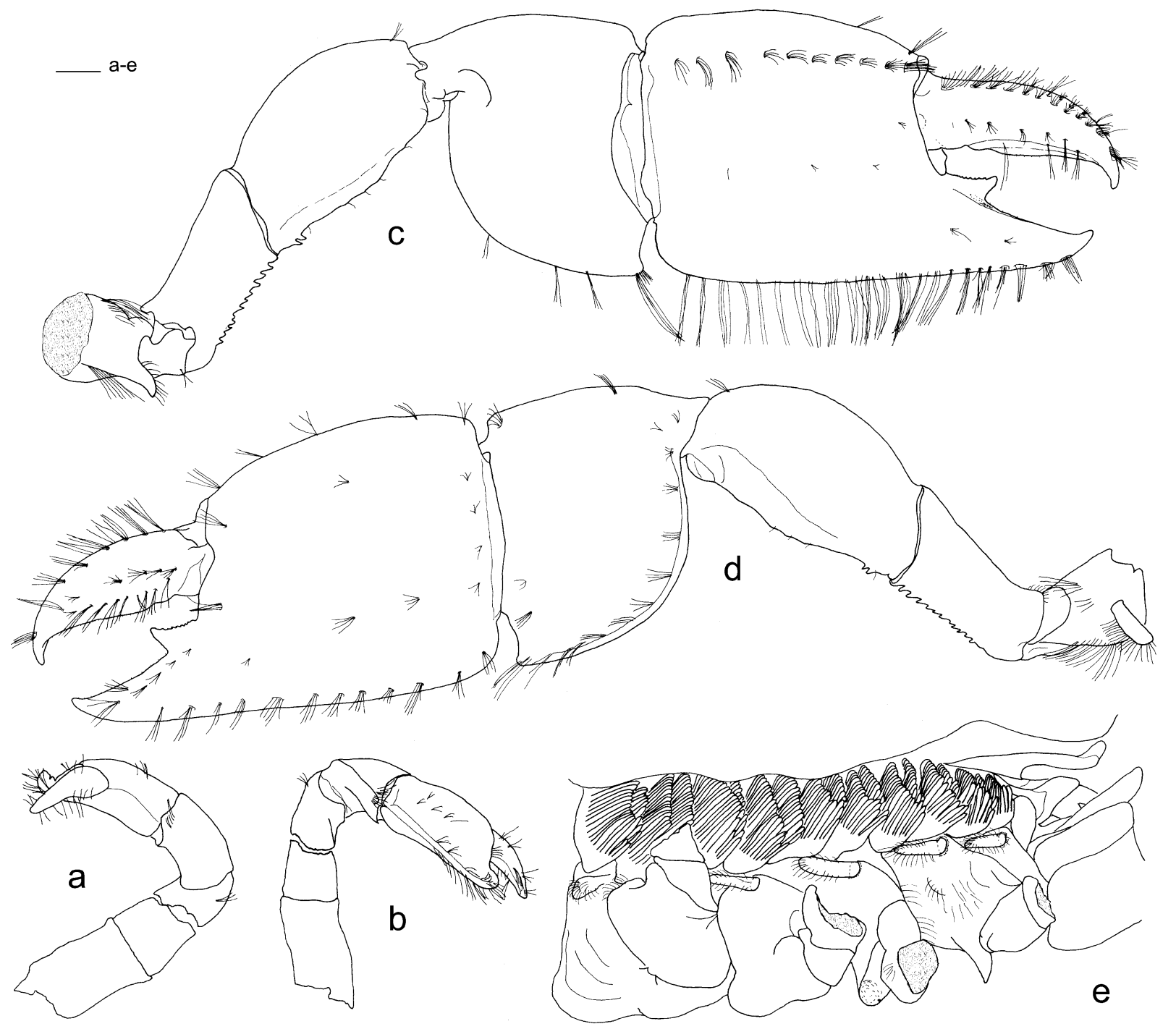

FIGURE 3. Vulcanocalliax arutyunovi n.gen. n.sp., female holotype (NHMW 21927); a, b, mesial surface; b, d, lateral surface; e, ventrolateral aspect: a, b, right mutilated cheliped; c, d, left cheliped; e, right side of thorax (carapace lifted) to show coxae of maxilliped 3 and pereopods 1-4, epipods and arthrobranchs. Scale line indicates $1 \mathrm{~mm}$.

Second maxilla (Fig. 2f) with endopod narrowed at distal end, terminus directed mesially, first and second endites each longitudinally subdivided, exopod forming large, broad scaphognathite.

First maxilliped (Fig. 2g) with endopod reduced; proximal endite triangular; distal endite elongate, lateral surface and all margins heavily setose, mesial surface concave; exopod triangular, no transverse suture; distal part broad, with long marginal setation at its mesial end, proximal part with field of mesially directed setae near mesial end; epipod large, broad, anterior end tapered, angular.

Second maxilliped (Fig. 2h) with long endopod; merus straight, mesial surface concave, slightly thicker in proximal half than in distal, inferior margin with dense fringe of long, close-set setae; carpus short; propodus weakly arcuate, length 1.3 times width, less than $1 / 3$ length of merus; dactylus short, about $1 / 2$ length of propodus, tip with dense setae; exopod as long as endopodal merus and carpus combined, fringed marginally by long setae; epipod small, leaf-shaped, arthrobranch (not shown) greatly reduced. 
Third maxilliped (Fig. 2i, j) without exopod; endopod with long dense setation on mesial margin; endopodal ischium subrectangular, 1.5 times as long as broad, proximomesial lip rounded, mesial surface with medial longitudinally oriented elevation bearing well-defined curved row of 15 sharp teeth; merus subquadrate, as broad as long, mesial surface with setose elevation proximally; carpus strongly flexed in proximal third with setose lobe on inferior margin; propodus large, subrectangular, 1.2 times as long as broad; dactylus subtriangular, broad terminally, as long as broad, fringed with very dense field of close-set, stiff, serrated setae on broad terminal margin.

Branchial formula (Table 1) includes exopods and epipods as described for first, second and third maxillipeds above; branchiae limited to single arthrobranch on second maxilliped, pair of arthrobranchs on third maxilliped, and pair of arthrobranchs on each of the first through fourth pereopods (Fig. 3e).

TABLE 1. Branchial formula in Vulcanocalliax arutyunovi n.gen. n.sp. ( $\mathrm{r}=$ rudimentary)

\begin{tabular}{lllllllll}
\hline & Mxp1 & Mxp2 & Mxp3 & P1 & P2 & P3 & P4 & P5 \\
\hline arthrobranchs & - & 1 & 2 & 2 & 2 & 2 & 2 & - \\
podobranchs & - & - & - & - & - & - & - & - \\
epipods & 1 & 1 & 1 & 1 & 1 & 1 & r & - \\
exopods & 1 & 1 & - & - & - & - & - & - \\
\hline
\end{tabular}

Left (presumably minor) cheliped (Fig. 3c, d) strongly calcified; coxa with strong, posteriorly curved spine posteriomesially, simple epipod laterally; ischium stout, superior margin almost straight, inferior margin with spines increasing in size distally, length about 1.5 times distal breadth; merus stout, length about 2 times breadth at midlength, superior margin curved, inferior margin with two spines proximally, slightly undulated at midlength; carpus broad, broadest distally, inferior margin arcuate and keeled, terminating in rounded projection, superior margin slightly curved; propodus heavy, length (including fixed finger) about 1.6 times height, mesial surface of palm smooth; superior and inferior propodal margins slightly curved, tufts of setae on inner face below superior margin and above inferior margin; fixed finger thick, prehensile margin armed with triangular tooth proximally, proximal superior margin of tooth with denticles, distal margin with few tiny corneous teeth, terminating in rounded tip; weakly unarmed excavation below the tooth on mesial face; dactylus heavy, curved, line of several setose punctae on mesial side of superior margin, lateral face with several setose punctae along inferior border, cutting edge with few tiny corneous teeth, tip strongly curved posteriomesially.

Right (presumably major) cheliped apparently of same general shape as on left side, articles distal of ischium mutilated and distorted (Fig. 3a, b), obviously in state of incompletely regeneration.

Second pereopod (Fig. 4a) chelate, most of inferior margins of ischium and merus lined with evenly spaced long setae, similar setae restricted primarily to distal patches on inferior margin in carpus, inferior margin of propodus with similar setal patches, which are long proximally, progressively more reduced in length and stiffened distally, subterminally becoming dense patch of short, stiff bristles; prehensile margins of both fingers corneous, finely microserrate along straight edge over most of length, microserration terminating distally in corneous tips of fingers; superior margin of dactylus straight, with patches of stiff, arched bristles becoming increasingly reduced in length, close-set and more arched distally.

Third pereopod (Fig. 4b) ischium short, 0.3 times length of merus; merus length about 2.5 times breadth, inferior margin weakly sinuous, with several tufts of setae; carpus broadly flared distally to produce strong inferior lobe, width there about 0.7 times length, inferior lobe terminally with field of long arched setae, diminishing in length toward articulation with propodus; propodus oval, 0.9 times as broad as long, inferior margin terminally with field of long arched setae diminishing in size distally along margin, becoming closeset shorter bristles at distal extreme, superior margin with tufts of arched setae, patterned tufts of thinner setae 
on lateral face of article; dactylus tear-shaped, length about 2.5 times width, terminating in narrow tip hooked toward lateral side, inferior margin sinuous, lateral face crossed by fields of short setae, longest near superior margin, with separate, dense field of slightly heavier short setae along lower extreme of lateral face and inferior margin.
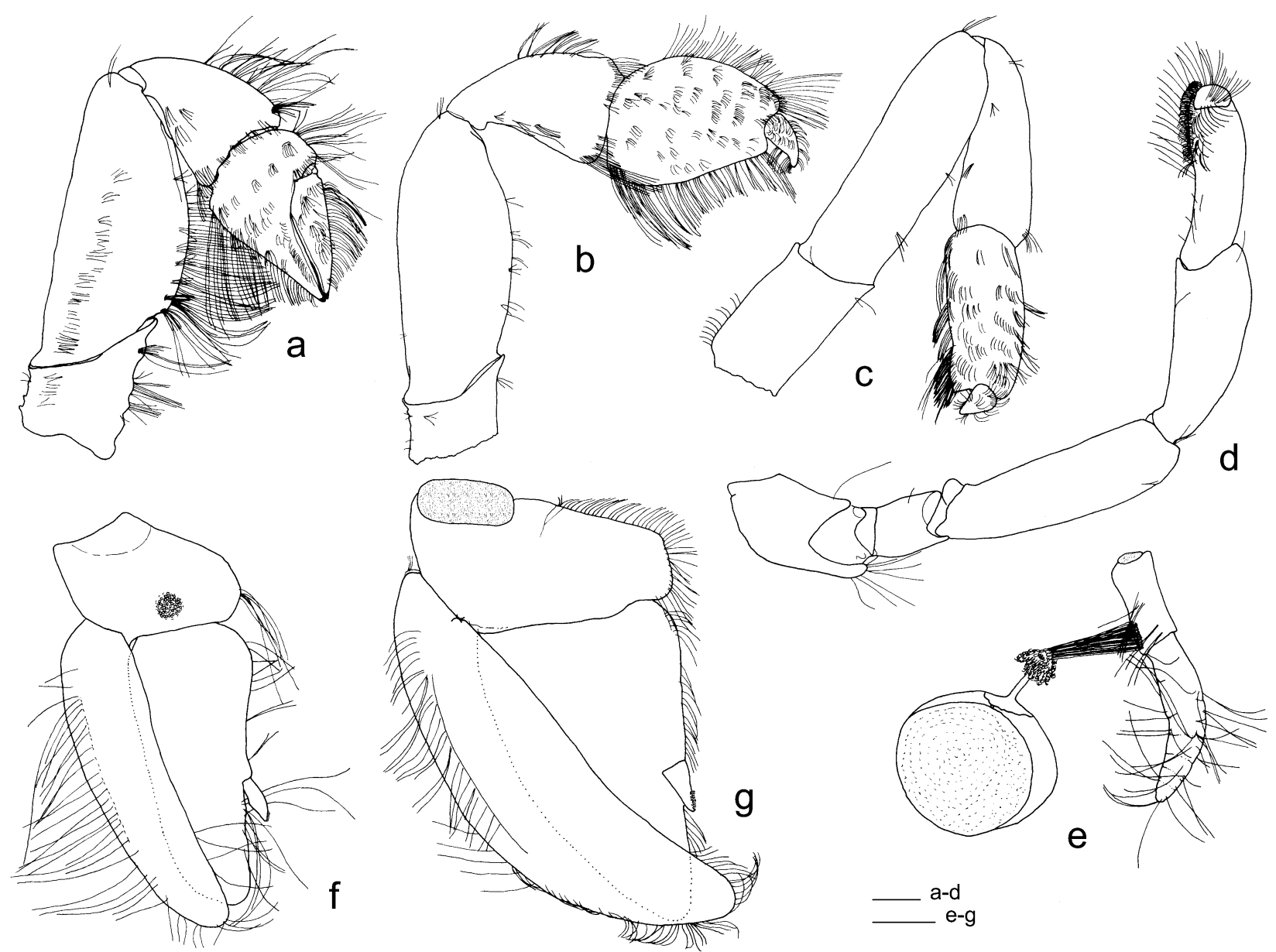

FIGURE 4. Vulcanocalliax arutyunovi n.gen. n.sp., female holotype (NHMW 21927), right appendages; a-d, lateral surface; e, posterior surface; f, g, anterior surface: a, second pereopod; b, third pereopod; c, fourth pereopod; d, fifth pereopod; e, first pleopod; f, second pleopod (ovigerous setae and embryos removed); g, third pleopod. Scale lines indicate $1 \mathrm{~mm}$.

Fourth pereopod (Fig. 4c) not subchelate, inferodistal corner of propodus rounded without evidence of fixed finger; dense setation on lateral surface of both propodus and tear-shaped dactylus divided into upper and lower fields, setae thicker in lower fields of propodus, especially on and near inferior margin, proximally field of thick, serrate setae near articulation with dactylus.

Fifth pereopod (Fig. 4d) minutely chelate, opposable surfaces of propodus and minute dactylus excavate, spooned, terminally rounded, forming beak-like chela obscured by dense fields of setation on distal 1/2 of propodus and superior surface of dactylus.

Abdomen long (Fig. 1a, b); dorsal length ratio (along midline) of first to sixth abdominal somites: 1.0: 1.14: 0.71: 0.75: 0.71: 0.75. First somite slightly narrowed anteriorly, pleuron triangular with acute triangular projections anterolaterallly and straight ventral margin. Second somite with straight anterior margin, posterior margin expanded posterolaterally, with one setal tuft near the posterior margin, ventral and posterior margin bearing setae. Third to fifth somites each distinctly shorter than second somite, posterior margins expanded 
posterolaterally; pleura each with row of plumose setae midlaterally and simple setae on posteroventral margin. Sixth somite trapezoid in dorsal view, narrowed posteriorly, ventral margin of pleurite with short setae, posterior margin with tuft of long setae on each side, another on posterolateral margin.

First female pleopod uniramous (Fig. 4e), composed of two articles, total length $2 / 3$ that of second pleopod, proximal article half as long as distal article, few long setae distally on posterior face, distally on mesial face one field of strong ovigerous setae terminally surrounded by a branched structure connecting via a funiculus to a single embryo; terminal article strongly curved posteriorly, with few long setae on mesial and lateral margins.

Second female pleopod biramous, with appendix interna (Fig. 4f); dense setation largely restricted to distal lobe of basipod, lateral margin of exopod, and mesial margin of endopod; bearing small appendix interna with cincinnuli; four fields of ovigerous setae on posterior face, one on anterior face.

Third to fifth pleopod pairs (Fig. 4g) forming large, posteriorly cupped fans when cross-linked by hooked setae of appendices internae on opposed margins of endopods; endopod of each triangular. Appendices internae stubby, movably articulated to mesial margin of endopod. Third pleopod with four fields of ovigerous setae on posterior surface. Total of 30 embryos on pleopods, $2.2-2.7 \mathrm{~mm}$ in diameter.

Telson (Figs. 1h) about 1.2 times as long as broad, broadest proximally, narrowing distally, posterolateral margin rounded, with few short simple setae, dorsal surface with one tuft of long, dorsally directed setae and two low tubercles at $1 / 4$ length.

Uropod with endopod oval, 1.7 times as long as broad (Fig. 1b, g), overreaching telson, posterolateral and posterior margins with few simple setae, dorsal surface convex with indistinct longitudinal carina; exopod oval, 2 times as long as broad, posterior margin of anterodorsal plate strongly curved and descending to distal margin, anterior part of plate depressed, distal edge of plate lined with short, thick spiniform setae and simple setae, posterodistal margin of exopod with few simple setae.

Description of male allotype: Body and appendages generally similar to that of female holotype (Fig. 5a) with the following exceptions:

Carapace smooth laterally.

Major and minor chelipeds in male allotype slightly unequal in size, similar in shape between the right and the left (Fig. 5b-e), both with sharp triangular tooth on cutting edge of fixed finger; merus of major cheliped with one proximal ventral spine, that of minor with 2 spines; major cheliped with ischium and merus as long, merus 1.13 times the height, carpus 1.15 times the height and length, and propodus (including fixed finger) 1.2 times the height and 1.11 times the length of these articles in the minor cheliped, dactylus more curved in major than in minor cheliped.

Male gonopore mesially on coxa of fifth pereopod. First pleopod of male (Fig. 5f) vestigial, consisting of two articles, not yet fully developed.

Second pleopod of male (Fig. 5g) biramous, with appendix interna on endopod; setae on mesial and lateral margins of both endopod and exopod, endopod shorter than exopod.

Etymology: The species is named after the late Alexander B. Arutyunov, former captain of RV Prof. Logachev, whose name also graces the type locality, the mud volcano "Captain Arutyunov" in the Gulf of Cádiz.

Colour (from notes and colour photographs of specimens taken immediately after sampling): Pale white.

Ecology: The specimens were found in two grab samples collected from the outer rim of the crater where sediments were mud breccia with a smooth surface. The callianassids were accompanied by over 40 other benthic species, among them abundant siboglinid polychaetes and desmosomatid isopods, several other aselotte isopods, and varied species of small molluscs. Other samples collected in the more disturbed and active central areas of the crater did not yield any callianassid specimens.

Distribution: Known only from the type locality; North Atlantic, Gulf of Cádiz, Captain Arutyunov mud volcano, 1327-1339 m, in mud breccia with smooth surface. 


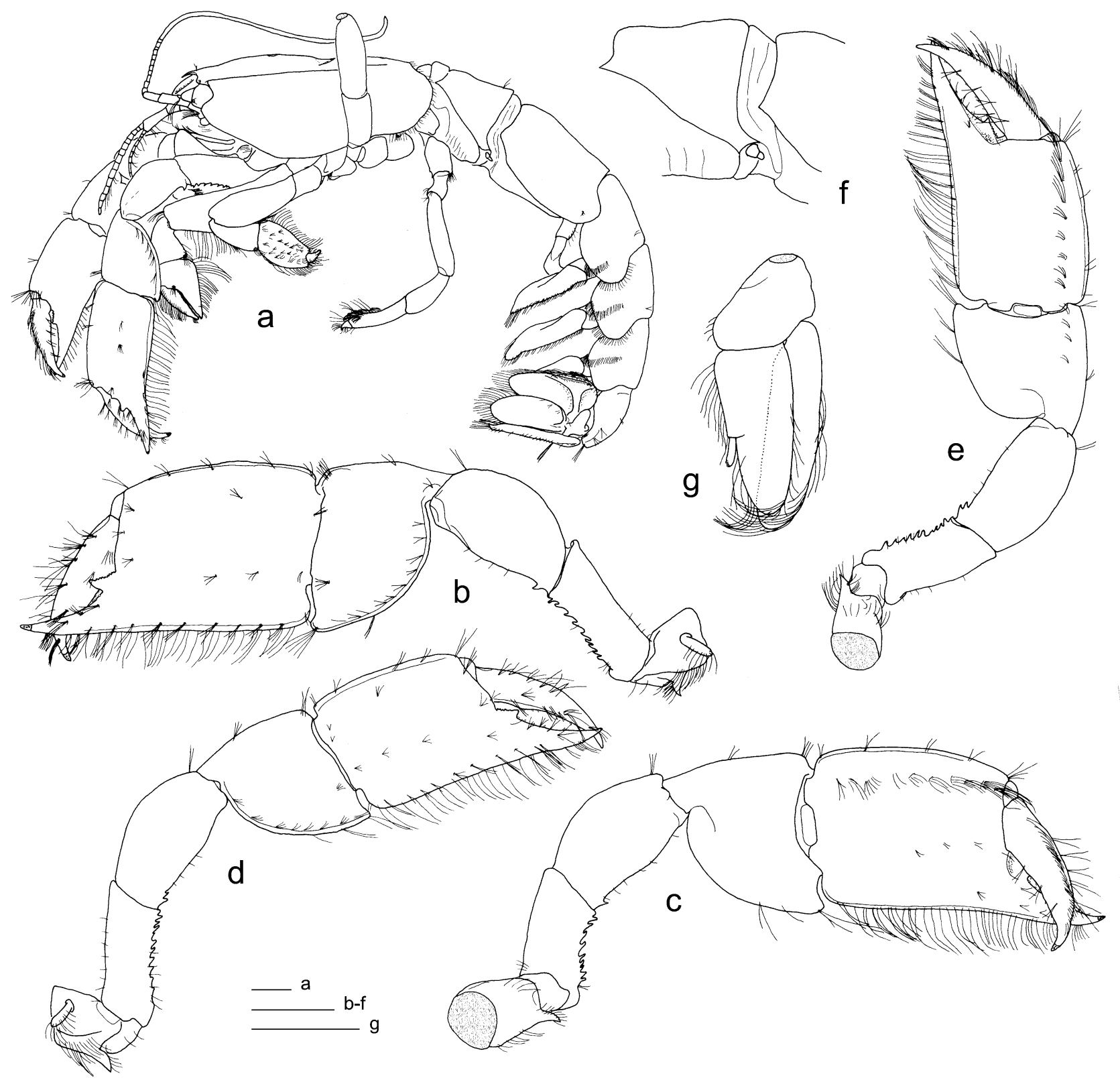

FIGURE 5. Vulcanocalliax arutyunovi n.gen. n.sp., male allotype (NHMW 21928); a, b, d, f, lateral aspect; c, e, mesial surface; g, posterior surface; a, habitus; b, c, left major cheliped; d, e, right minor cheliped; f, abdominal somite with first pleopod; g, second right pleopod. Scale lines indicate $1 \mathrm{~mm}$.

Remarks: Vulcanocalliax arutyunovi n.gen. n.sp. is most closely related to Bathycalliax geomar (see remarks above). Both species have one unique character among the Callianassidae, the presence of epipods on Mxp3 and P1 to P4. Epipods are found in some other thalassinidean families, e.g. the Laomediidae and the Axiidae. In these cases, however, they are much more differentiated, showing anterior and posterior lobes as well as podobranchs in variable numbers. In Vulcanocalliax arutyunovi n.gen. n.sp. as well as in Bathycalliax geomar (SMF 23866, 23867), the epipods are rather simple (see Fig. 3e). Sakai \& Türkay (1999: table 1) mentioned an epipod and a podobranch for Mxp2 in Bathycalliax geomar. Investigation of the type material, however, showed that this appendage has also a well-developed arthrobranch.

It should be noted that only the male holotype of B. geomar (SMF 23866) has Plp1 as described and figured by Sakai \& Türkay (1999: 208, fig. 1). The male paratype (SMF 23867) lacks any signs of Plp1. This 
specimen shows numerous stalked ellipsoid bodies $(0.780 .36 \mathrm{~mm})$ attached ventrally to the cuticle between the coxae of P5 and on abdominal somites 1 to 6 . These are most probably externae of a rhizocephalan cirriped of the family Thompsoniidae Høeg \& Rybakov, 1992. Between the externae are numerous scars of externae that dropped off. Such scars occur also in the holotype (SMF 23866).

Another unique character of Vulcanocalliax arutyunovi n.gen. n.sp. is the anterolateral projections of the first abdominal somite (Fig. 1a, b). Such anterolateral projections are present in other thalassindean familes, e.g. Laomediidae and Axiidae. In those families, however, the lobes ride on posterolateral carapace ridges (see Poore, 1994). A posterolateral lobe of the carapace with ridges is missing in the new species. The anterolateral projections of the first abdominal somite in Vulcanocalliax are therefore not considered to be homologous with those in the Laomediidae and Axiidae.

Remarkable is also the large size and low number of embryos in the new species. With only 30 embryos, 2.2 to $2.7 \mathrm{~mm}$ in diameter, these are the fewest in number and the largest ever reported for Callianassidae (see summaries in Pezzuto, 1998 and Corsetti \& Strasser, 2003). Large and few embryos generally indicate an abbreviated larval development typical for restricted and specialised habitats (Rabalais \& Gore, 1985).

The attachment system of the embryos is also unique. Their big size allows only a single embryo to be attached to a dense patch of thick setae (see Fig. 4e). In other callianassids, several small eggs are usually attached to a single seta via an investment coat and funiculi (P.C.Dworschak, pers. obs., see also Saigusa $e t$ al., 2002)

\section{Acknowledgements}

The second author wishes to acknowledge the co-chief-scientists Luís Pinheiro (Departamento de Geociências, Universidade de Aveiro) and Michael Ivanov (Moscow State University) for the invitation to participate in the TTR 12 cruise (Training-Through-Research Programme, IOC-UNESCO). Thanks are also due to Pieter Van Rensbergen and Bart Pannemans (Renard Centre of Marine Geology) for the facies description and interpretation of the side-scan image of Captain Arutyunov mud volcano. The senior author thanks Michael Türkay (SMF) for the loan of Bathycalliax geomar. This research is a contribution to the HERMES project, EC contract no GOCE-CT-2005-511234, funded by the European Commission's Sixth Framework Programme under the priority 'Sustainable Development, Global Change and Ecosystems'. The manuscript benefited from the constructive comments of Darryl Felder and Rafael Lemaitre.

\section{References}

Corsetti, J.L. \& Strasser, K.M. (2003) Population biology of the ghost shrimp Sergio trilobata (Biffar 1970) (Crustacea: Decapoda: Thalassinidea). Gulf and Caribbean Research, 15, 13-19.

Dana, J.D. (1852) Conspectus of the Crustacea of the exploring expedition under Capt. Wilkes, U.S.N. Proceedings of the Academy of Natural Sciences of Philadelphia, 6, 6-28.

Felder, D.L. \& Kensley, B. (2004) A new species of axiid shrimp from chemosynthetic communities of the Louisiana continental slope, Gulf of Mexico (Crustacea: Decapoda: Thalassinidea). Proceedings of the Biological Society of Washington, 117(1), 68-75.

Giard, A. \& Bonnier, J. (1890) Sur une espce nouvelle de Callianasse du Golfe de Naples (Callianassa truncata). Bulletin Scientifique de France et de la Belgique, 22, 362-366.

Høeg, J.T. \& Rybakov, A.V. (1992) Revision of the Rhizocephala Akentrogonida (Cirripedia), with a list of all species and a key to the identification of families. Journal of Crustacean Biology, 12, 600-609.

Ivanov, M.K., Limonov, A.F. \& Woodside, J.M. (1998) Extensive deep fluid flux through the sea floor on the Crimean continental margin (Black Sea). In: J.P. Henriet \& Mienert, J. (Eds) Gas hydrates relevance to world margin stability and climate change. Geological Society, London, Special Publications, 137, 185-213. 
Kenyon, N.H., Ivanov, M.K., Akhmetzanov, A.M. \& Akhmanov, G.G. (Eds.) (2000) Multidisciplinary study of geological processes on the North East Atlantic and Western Mediterranean Sea margins. IOC Technical Series, 56, 102 pp.

Kenyon, N.H., Ivanov, M.K., Akhmetzanov, A.M. \& Akhmanov, G.G. (Eds.) (2003) Interdisciplinary Geoscience Research on the North East Atlantic margin, Mediterranean Sea and Mid-Atlantic Ridge during the TTR12 cruise of RV Prof. Logachev, June-August 2002. IOC Technical Series, 67, 156 pp.

Kishinouye, K. (1926) Two rare and remarkable forms of macrourous Crustacea from Japan. Japanese Journal of Zoology, 11, 63-70.

Manning, R.B. \& Felder, D.L. (1991) Revision of the American Callianassidae (Crustacea, Decapoda, Thalassinidea). Proceedings of the Biological Society of Washington, 104, 764-792.

Martin, J.W. \& Haney, T.A. (2005) Decapod crustaceans from hydrothermal vents and cold seeps: a review through 2005. Zoological Journal of the Linnean Society 145, 445-522.

Olu, K., Lance, S., Sibuet, M., Henry, P., Fiala-Médioni, A. \& Dinet, A. (1997) Cold seep communities as indicators of fluid expulsion patterns through mud volcanoes seaward of the Barbados accretionary prism. Deep-Sea Research I, 44 (5), 811-841.

Pezzuto, P.R. (1998) Population dynamics of Sergio mirim (Rodrigues 1971)(Decapoda: Thalassinidea: Callianassidae) in Cassino Beach, Southern Brazil. Pubblicazioni della Stazione Zoologica di Napoli: Marine Ecology, 19, 89-109.

Pinheiro, L.M., Ivanov, M.K. Sautkin, A. Akhmanov, G. Magalhães, V.H. Volkonskaya, A. Monteiro, J.H. Somoza, L. Gardner, J. Hamouni, N. \& Cunha, M.R. (2003) Mud volcanism in the Gulf of Cádiz: results from the TTR-10 cruise. Marine Geology, 195, 131-151.

Poore, G.C.B. (1994) A phylogeny of the families of Thalassinidea (Crustacea: Decapoda) with keys to families and genera. Memoirs of the Museum of Victoria, 54, 79-120.

Powell, A.W.B. (1949) New species of Crustacea from New Zealand of the genus Scyllarus and Ctenocheles with notes on Lyreidus tridentatus. Records of the Auckland Institute and Museum, 3, 368-371.

Rabalais, N.N., \& Gore, R.H. (1985) Abbreviated development in decapods. In: Wenner, A.M. (ed.), Larval growth. Crustacean Issues, 2, 67-126. A.A.Balkema, Rotterdam.

Saigusa, M., Terajima, M. \& Yamamoto, M. (2002) Structure, formation, mechanical properties, and disposal of the embryo attachment system of an estuarine crab, Sesarma haematocheir. Biological Bulletin, 203, 289-306.

Sakai, K. (1999a) Redescription of Ctenocheles balssi Kishinouye, 1916, with comments on its systematic position and establishment of a new subfamily Gourretiinae (Decapoda, Callianassidae). Crustaceana, 72, 85-97.

Sakai, K. (1999b) Synopsis of the family Callianassidae, with keys to subfamilies, genera and species, and the description of new taxa (Crustacea: Decapoda: Thalassinidea). Zoologische Verhandelingen, 326, 1-152.

Sakai, K. (2005) Callianassoidea of the world (Decapoda, Thalassinidea). Crustaceana Monographs, 4, 1-200.

Sakai K. \& Türkay, M. (1999) A new subfamily, Bathycalliacinae n. subfam., for Bathycalliax geomar n. gen., n. sp. from the deep water cold seeps off Oregon, USA (Crustacea, Decapoda, Callianassidae). Senckenbergiana Biologica 79(2), 203-209.

Sibuet, M. \& Olu, K. (1998) Biogeography, biodiversity and fluid dependence of deep-sea cold-seep communities at active and passive margins. Deep-Sea Research II, 45, 517-567.

Stadnitskaia, A., Ivanov, M.K. Blinova, V. Kreulen, R. \& Weering, T. van (2006) Molecular and carbon isotopic variability of hydrocarbon gases from mud volcanoes in the Gulf of Cádiz, NE Atlantic. Marine and Petroleum Geology, 23, 281-296.

Türkay, M. \& Sakai, K. (1995) Decapod crustaceans from a volcanic hot spring in the Marianas. Senckenbergiana maritima, 26(1-2), 25-35.

Van Rensbergen, P., Depreiter, D., Pannemans, B., Moerkerke, G. Van Rooij, D., Marsset, B., Akhmanov, G., Blinova, V., Ivanov, M., Rachidi, M., Magalhães, V., Pinheiro, L., Cunha, M. \& Henriet, J.-P. (2005) The El Arraiche mud volcano field at the Moroccan Atlantic slope, Gulf of Cádiz. Marine Geology, 219, 1-17. 